Artikel Penelitian

\title{
Hubungan Status Gizi dengan Kejadian Anemia pada Remaja Putri di SMAN 2 Sawahlunto Tahun 2014
}

\author{
Fhany El Shara ${ }^{1}$, Irza Wahid² ${ }^{2}$ Rima Semiarti ${ }^{3}$
}

\begin{abstract}
Abstrak
Anemia merupakan suatu keadaan dimana kadar Hemoglobin $(\mathrm{Hb})$ seseorang dalam darah lebih rendah dari normal. Remaja putri merupakan salah satu kelompok yang berisiko menderita anemia. Berbagai penelitian di beberapa daerah di Indonesia masih menunjukkan tingginya prevalensi anemia pada remaja putri. Berdasarkan hasil skrining tahunan yang dilakukan oleh Dinas Kesehatan Kota Sawahlunto tahun 2013 terhadap siswa putri tingkat SMP dan SMA di Kota Sawahlunto diperoleh prevalensi anemia yang juga tinggi. Prevalensinya lebih banyak ditemukan pada siswa SMA dengan persentase 57,9\% dengan angka kejadian tertinggi di SMAN 2 Sawahlunto (71,8\%) Tujuan penelitian ini adalah menentukan hubungan antara status gizi dan kejadian anemia pada remaja putri di SMAN 2 Sawahlunto. Penelitian ini merupakan studi observasional dengan rancangan cross sectional. Selama periode Agustus-Desember 2014 dilakukan pengambilan data meliputi pengukuran berat badan, tinggi badan dan pemeriksaan $\mathrm{Hb}$ menggunakan metode Cyanmethemoglobin terhadap siswa remaja putri kelas X dan XI SMAN 2 Sawahlunto. Data diuji dengan chi-square. Hasil uji statistik menunjukkan nilai $p$ adalah $0,008(p<0,05)$. Simpulan studi ini ialah terdapat hubungan bermakna antara status gizi dan kejadian anemia pada remaja putri di SMAN 2 Sawahlunto.
\end{abstract}

Kata kunci: anemia, remaja putri, status gizi

\begin{abstract}
Anemia is low level of Hemoglobin concentration in the blood. Adolescent girl is one of the groups at high risk of anemia. Some researchs in Indonesia show that the prevalence of anemia among adolescent girls is so high. Based on annual screening among adolescent girls in 2013 in Sawahlunto is obtained 57,9\% prevalence of anemia. The highest incidence was found in SMAN 2 Sawahlunto (71,8\%). The objective of this study was to determine relationship between nutritional status and anemia among adolescent girls in SMAN 2 Sawahlunto. The cross sectional study design was conducted from August to December 2014. The participants were female students of grade X, XI in SMAN 2 Sawahlunto. The data was collected by measuring weight, height, and Hb. Later, the data were analyzed by employing statistical analysis. The incidence of anemia was $70,7 \%$ and most of respondents had normal nutritional status $(51,2 \%)$. The results of the chi-square test was $0.008(p<0.05)$. The conclusion is a significant association between nutritional status and the incidence of anemia in adolescent girls in SMAN 2 Sawahlunto.
\end{abstract}

Keywords: adolescents girls, anemia, nutritional status

Affiliasi penulis: 1. Prodi Profesi Dokter FK Unand (Fakultas Kedokteran Universitas Andalas Padang), 2. Bagian IImu Penyakit Dalam FK Unand/RSUP Dr. M. Djamil Padang, 3. Bagian IImu Kesehatan Masyarakat FK Unand

Korespondensi: Fhany El Shara. Email: fhanyelshara@gmail.com Telp: 0812-6640-8686

\section{PENDAHULUAN}

Remaja putri merupakan salah satu kelompok yang berisiko tinggi menderita anemia. Mereka adalah calon pemimpin di masa datang, calon tenaga kerja yang akan menjadi tulang punggung produktivitas 
nasional, serta yang paling penting adalah sebagai calon ibu yang akan melahirkan generasi penerus dan merupakan kunci perawatan anak di masa datang. Remaja putri perlu mendapat perhatian yang serius dan dipersiapkan untuk menjadi calon ibu yang sehat. ${ }^{1}$

Remaja putri lebih rentan terkena anemia karena remaja berada pada masa pertumbuhan yang membutuhkan zat gizi yang lebih tinggi. Adanya siklus menstruasi setiap bulan merupakan salah satu faktor penyebab remaja putri mudah terkena anemia. ${ }^{2}$

Berdasarkan data yang diperoleh dari World Health Organization (WHO) pada tahun 2008, anemia merupakan salah satu masalah gizi yang masih menjadi masalah kesehatan masyarakat dunia terutama di negara berkembang. Survei prevalensi anemia yang dilakukan WHO dari tahun 1993-2005 menunjukkan angka 48,8\% terhadap insiden anemia secara global. Berdasarkan data tersebut, 73,5\% ditemukan pada kelompok populasi Non-Pregnant Woman (NPW). Region Asia menempati posisi kedua teratas setelah Afrika terhadap tingginya prevalensi anemia. Menurut WHO tahun 2008,45,7\% anemia terjadi di Asia Tenggara. Berdasarkan data tersebut, prevalensi anemia tahun 1993-2005 di Indonesia mencapai $33,1 \%$. Angka ini lebih tinggi di bandingkan negara-negara Asia Tenggara lainnya seperti Brunei $(20,4 \%)$, Malaysia $(30,1 \%)$, Vietnam $(24,3 \%)$, dan Thailand $(17,8 \%)^{3}$

Prevalensi anemia di tingkat nasional juga masih menunjukkan angkayang cukup tinggi. Survei kesehatan rumah tangga (SKRT) tahun 2005, menunjukkan bahwa prevalensi anemia pada remaja putri usia $10-14$ tahun $57,1 \%$ dan pada Wanita Usia Subur (WUS) usia 17-45 tahun sebesar 39,5\%. ${ }^{4}$ Anemia menjadi masalah kesehatan masyarakat karena prevalensi nya diatas $20 \%{ }^{5}$

Beberapa hasil penelitian di beberapa daerah di Indonesia juga menunjukkan masih tingginya prevalensi anemia pada remaja putri. Penelitian Leginem tahun 2002 di Kota Banda Aceh mendapatkan prevalensi anemia pada remaja putri yaitu sebesar $88 \%$. Penelitian Satyaningsih tahun 2007 pada remaja putri SMK Amaliyah Sekadau Kalimantan Barat mendapatkan prevalensi anemia yaitu $58,7 \%$. ${ }^{6,7}$
Berdasarkan hasil skrining tahunan yang dilakukan oleh Dinas Kesehatan Kota Sawahlunto tahun 2013 tentang anemia pada remaja putri tingkat SMP dan SMA di Kota Sawahlunto diperoleh prevalensi anemia yang juga cukup tinggi. Prevalensinya lebih banyak ditemukan pada siswa SMA dengan persentase $57,9 \%$ dengan angka kejadian tertinggi di SMAN 2 Sawahlunto yaitu sebesar $71,8 \%{ }^{8}$

\section{METODE}

Penelitian ini merupakan jenis penelitian observasional dengan rancangan cross sectional. Pada penelitian ini dilakukan pengukuran berat badan, tinggi badan dan kadar $\mathrm{Hb}$ terhadap 123 orang siswa remaja putri kelas I dan II SMAN 2 Sawahlunto. Kriteria inklusi adalah semua siswa yang bersedia menjadi responden dengan menandatangani informed consent, sedangkan kriteria ekslusi adalah remaja putri yang memiliki riwayat haid abnormal, pindah sekolah dan yang menderita penyakit kronis.

Data diperoleh dari data primer dan data sekunder. Data primer diperoleh secara langsung melalui pengukuran berat dan tinggi badan untuk menghitung status gizi dengan cara menghitung Indeks Massa Tubuh (IMT) dan pengukuran kadar hemoglobin dengan metode Cyanmethemoglobin oleh petugas laboratorium Puskesmas Sei Durian Kota Sawahlunto. Data sekunder diperoleh dari Dinas Kesehatan Kota Sawahlunto tentang hasil skrining anemia pada remaja putri dan data siswa dari SMAN 2 Sawahlunto. Selanjutnya dilakukan pengolahan dan analisis data menggunakan uji chi-square secara komputerisasi. Hasil penelitian disajikan dalam bentuk tabel.

\section{HASIL}

Tabel 1 memperlihatkan distribusi frekuensi status gizi remaja putri di SMAN 2 Sawahlunto.

Tabel 1. Distribusi frekuensi status gizi

\begin{tabular}{lcc}
\hline \multicolumn{1}{c}{ Status Gizi } & Frekuensi & (\%) \\
\hline Kurus & 52 & 42,3 \\
Normal & 63 & 51,2 \\
Gemuk & 8 & 6,5 \\
\hline \multicolumn{1}{c}{ Jumlah } & 123 & 100 \\
\hline
\end{tabular}


Pada tabel 1 terlihat status gizi terbanyak pada subjek penelitian adalah status gizi normal dengan jumlah 63 orang siswa $(51,2 \%)$ dan yang paling sedikit adalah siswa dengan status gizi gemuk, yaitu hanya 8 orang siswa $(6,5 \%)$.

Tabel 2. Distribusi frekuensi anemia berdasarkan kadar Hemoglobin

\begin{tabular}{lcc}
\hline \multicolumn{1}{c}{ Kadar Hb (g/d) } & Frekuensi & $\mathbf{( \% )}$ \\
\hline$<12$ (Anemia) & 87 & 70,7 \\
$\geq 12$ (Tidak Anemia) & 36 & 29,3 \\
\hline \multicolumn{1}{c}{ Jumlah } & 123 & 100 \\
\hline
\end{tabular}

Berdasarkan Tabel 2 dapat dilihat bahwa siswa remaja putri SMAN 2 Sawahlunto yang mengalami anemia sebanyak 87 orang (70,7\%), sedangkan siswa yang tidak mengalami anemia sebanyak 36 orang $(29,3 \%)$.

Tabel3. Hubungan status gizi dengan kejadian anemia

\begin{tabular}{|c|c|c|c|c|c|c|c|c|}
\hline \multirow{3}{*}{ Anemia } & \multicolumn{6}{|c|}{ Status Gizi } & \multirow{3}{*}{$\mathbf{p}$} & \multirow{3}{*}{$\begin{array}{c}\text { OR } \\
(95 \% \\
\text { Cl) }\end{array}$} \\
\hline & \multicolumn{2}{|c|}{ Kurus } & \multicolumn{2}{|c|}{ Normal } & \multicolumn{2}{|c|}{ Gemuk } & & \\
\hline & $f$ & $\%$ & $f$ & $\%$ & 1 & $\%$ & & \\
\hline $\mathrm{Ya}$ & 41 & 78,8 & 44 & 69,8 & 2 & 25,0 & & \\
\hline Tidak & 11 & 21,2 & 19 & 30,2 & 6 & 75,0 & 0,008 & 0,089 \\
\hline Total & 52 & 100 & 63 & 100 & 8 & 100 & & \\
\hline
\end{tabular}

Pada Tabel 3 dapat dilihat bahwa remaja putri dengan status gizi kurus yang menderita anemia, yaitu sebesar 78,8\%. Persentasenya lebih besar bila dibandingkan dengan responden dengan status gizi normal dan gemuk yang menderita anemia, yaitu $69,8 \%$ dan $25 \%$.

Hasil uji statistik chi-square menunjukkan nilai $p$ adalah 0,008, nilai OR adalah 0,089. Uji tersebut mendapatkan nilai $p<0,05$ yang berarti bahwa terdapat hubungan bermakna antara status gizi dengan kejadian anemia pada remaja putri di SMAN 2 Sawahlunto.

\section{PEMBAHASAN}

\section{Status Gizi}

Berdasarkan hasil penelitian, dari 123 sampel didapatkan 63 orang responden memiliki status gizi normal, 52 orang dengan status gizi kurus dan 8 orang dengan status gizi gemuk. Pada umumnya responden memiliki status gizi normal dengan rata-rata IMT sebesar $19,96 \mathrm{~kg} / \mathrm{m}^{2}$ tetapi banyak pula yang memiliki status gizi kurus dengan IMT paling rendah yaitu 16,01 $\mathrm{kg} / \mathrm{m}^{2}$. Penelitian yang dilakukan oleh Nur Widianti (2012) pada siswa SMA Theresiana Semarang juga menunjukkan bahwa sebagian besar responden memiliki status gizi normal $(59,7 \%) .{ }^{9}$ Hasil penelitian Mulyatni tahun 2002 yang dilakukan di Sekolah Menengah Umum Negeri dan Madrasah Aliyah Negeri di Kota Padang didapatkan status gizi kurang sebesar $30.7 \%$ dengan penyebaran $23.9 \%$ dengan status kekurangan gizi tingkat ringan (IMT 17.0 -18.5) dan $6.8 \%$ kekurangan gizi tingkat berat (IMT 17.0). ${ }^{10}$

Status gizi pada remaja putri sering dipengaruhi oleh perilaku makan dan body image. Penelitian Nur Widianti tahun 2012 menyatakan bahwa terdapat hubungan yang bermakna tentang perilaku makan dengan status gizi pada remaja putri ( $p=0,001$ ) Penelitian Laus et al tahun 2009 di Brazil menyatakan bahwa terdapat hubungan antara body image dengan status gizi $(p<0,01, r=0,37){ }^{11}$

Kebiasaan makan sehari-hari sangat berpengaruh terhadap pencapaian tubuh yang ideal, misalnya saja pembatasan asupan makanan agar berat badan tidak berlebih. Banyak remaja yang merasa tidak puas dengan penampilan dirinya sendiri, apalagi yang menyangkut tentang body image atau persepsi terhadap tubuhnya, dimana bentuh tubuh tinggi dan kurus merupakan hal yang diinginkan oleh remaja putri. Hal ini terkadang membawa pengaruh buruk, banyak remaja yang menerapkan pola makan tidak sehat demi mendapat tubuh ideal. Pola makan yang salah bisa meningkatkan risiko status gizi buruk. $^{12}$

Kekurangan gizi pada remaja terjadi akibat pembatasan konsumsi makanan dengan tidak memperhatikan kaidah gizi dan kesehatan sehingga asupan gizi secara kuantitas dan kualitas tidak sesuai dengan Angka Kecukupan Gizi yang dianjurkan. Pembatasan konsumsi makanan yang demikian justru berdampak negatif terhadap status gizi remaja. ${ }^{13}$

Pembatasan ini dipengaruhi oleh ketidak puasan body image. Ketidakpuasan pada remaja putri dengan menganggap tubuh gemuk ini membuat remaja melakukan upaya penurunan berat badan 
dengan pola yang salah sehingga hal tersebut akan mempengaruhi status gizi. Penelitian yang dilakukan oleh Kusumajaya et al ini juga menyatakan bahwa terdapat $12 \%$ remaja yang merasa gemuk padahal status gizi nya normal. ${ }^{13}$

\section{Anemia}

Anemia adalah suatu keadaan dimana kadar hemoglobin dalam darah berada di bawah batas normal. Pada remaja putri, batas kadar hemoglobin untuk anemia adalah $12 \mathrm{~g} / \mathrm{dl}^{5}$

Pada penelitian ini didapatkan prevalensi anemia pada remaja putri di SMAN 2 Sawahlunto sebesar $70,7 \%$ dengan rata-rata kadar $\mathrm{Hb}$ yaitu 11,32 $\mathrm{g} / \mathrm{dl}$. Hal ini sejalan dengan penelitian yang dilakukan oleh Kaur et al tahun 2006 terhadap remaja putri India, yaitu didapatkan rata-rata kadar $\mathrm{Hb}$ adalah 11,35 g/dl dengan prevalensi anemia sebesar 59,8\%. ${ }^{14}$

Penelitian yang dilakukan oleh Kaur et al tahun 2006 menyimpulkan bahwa remaja putri dengan asupan harian besi $<14 \mathrm{mg}$ cenderung akan menderita anemia $5 x$ lipat dibandingkan dengan remaja putri yang asupan hariannya $>20 \mathrm{mg}(\mathrm{OR}=5.09, \mathrm{Cl}=2.84-$ 9.11). Sedangkan remaja dengan asupan harian besi 14-20 mg juga akan cenderung menderita anemia sebesar $2 x$ lipat dibanding remaja putri yang asupan hariannya $>20 \mathrm{mg}(\mathrm{OR}=2.07, \mathrm{Cl}=1.17-3.64)$. Penelitian ini juga mendapatkan bahwa remaja dengan pola makan vegetarian akan cenderung berisiko terhadap kejadian anemia $(\mathrm{OR}=8.54, \mathrm{Cl}=5.7-12.8) .{ }^{14}$

Remaja putri termasuk salah satu kelompok yang rentan terhadap kejadian anemia. Ada banyak faktor yang dapat menyebabkan terjadinya anemia, salah satu faktor yang paling berkontribusi adalah defisensi zat besi. Hal ini terjadi akibat asupan nutrisi yang tidak mempertimbangkan menu seimbang yang meliputi unsur karbohidrat, lemak, protein, zat besi, vitamin, mineral dan lain lain. Pola konsumsi makanan juga mempunyai andil besar terhadap kejadian anemia. $^{15}$

\section{Hubungan Status Gizi dengan Anemia}

Hasil uji statistik chi-square dalam penelitian ini menunjukkan nilai $p$ adalah $0,008(p<0,05)$ yang berarti bahwa terdapat hubungan bermakna antara status gizi dengan kejadian anemia pada remaja putri di SMAN 2 Sawahlunto.

Pada hasil penelitian ini dapat dilihat bahwa semakin baik status gizi responden akan mengurangi risiko kejadian anemia. Hal ini sejalan dengan penelitian yang dilakukan oleh Yu Qin et al tahun 2013 di Cina yang menyatakan bahwa kadarhemoglobin cenderung meningkat seiring dengan peningkatan IMT. Responden yang overweight/obesitas memiliki risiko lebih kecil menderita anemia dibandingkan dengan responden yang memiliki status gizi normal (PR: 0.72, 95\% Cl: 0.62-0.89; PR: 0.59, 95\% Cl: 0.430.79). ${ }^{16}$

Penelitian lain yang mendukung adalah penelitian Ramzi et al tahun 2011 terhadap remaja putri di Kavar, Iran dimana ditemukan hubungan yang signifikan antara IMT dan kadar $\mathrm{Hb} .{ }^{17}$ Penelitian lain yang juga mendukung adalah penelitian oleh Eckhardt et al tahun 2008 yang dilakukan di tiga Negara, yaitu Mesir, Peru dan Meksiko. Dari hasil penelitian ini didapatkan bahwa prevalensi anemia cenderung berkurang dengan peningkatan IMT di Mesir dan Peru sedangkan hasil penelitian di Meksiko berbeda dimana tidak terdapat hubungan yang signifikan antara IMT dan anemia. ${ }^{18}$ Hal ini dapat terjadi karena beberapa faktor. Menurut Yu Qin et al tahun 2013 asupan besi dan vitamin C pada populasi Meksiko jauh lebih rendah daripada populasi lain dimana asupan harian besi hanya berkisar antara 8-9 $\mathrm{mg}$ dan asupan vitamin C kurang dari $30 \mathrm{mg} /$ hari. $^{16}$

Pada keadaan gizi buruk/kurang, asupan nutrisi berkurang, tubuh secara perlahan akan melakukan proses adaptasi. Secara berangsur-angsur terjadi wasting dari jaringan tubuh, metabolisme melambat, kebutuhan energi dan oksigen akan berkurang sehingga sel darah merah yang dibutuhkan untuk mengangkut oksigen tersebut juga akan berkurang. Jadi, pengurangan massa sel darah merah adalah konsekuensi normal dari pengurangan massa tubuh. Selain itu, pada saat asupan nutrisi berkurang terjadi pembatasan beberapa mikronutrien yang dibutuhkan dalam pembentukan sel darah merah. ${ }^{15}$

Sedangkan pada keadaan overweight / status gizi berlebih, anemia juga dapat terjadi. Berdasarkan penelitian ini didapatkan sebesar $25 \%$ responden 
dengan status gizi gemuk menderita anemia. Menurut Nead et al tahun 2004 pada keadaan ini ada beberapa faktor yang berperan, yaitu ada pengaruh genetik/ras dan asupan yang tidak adekuat dimana terbatasnya asupan makanan yang kaya besi. ${ }^{19}$ Menurut Nadia et al tahun 2011 hal ini dapat terjadi karena adanya inflamasi kronis dan peningkatan produksi leptin pada obesitas yang juga akan meningkatkan sekresi hepcidin dari hati yang mana hepcidin tsb dapat mengurangi absorpsi dari asupan $\mathrm{Fe}^{20}$

\section{SIMPULAN}

Terdapat hubungan yang bermakna antara status gizi dengan kejadian anemia.

\section{DAFTAR PUSTAKA}

1. Sakti. Pengaruh suplementasi tablet $\mathrm{Fe}$ dan pendidikan gizi terhadap pengetahuan, sikap, praktek tentang anemia dan konsentrasi hemoglobin $(\mathrm{Hb})$ pada remaja putri. Media Medika Indonesia. 2003;31(1):1-5.

2. Sediaoetama AD. IImu gizi untuk mahasiswa dan profesi jilid II. Jakarta: Dian Rakyat; 2006.

3. WHO. Worldwide Prevalence of Anaemia 19932005; WHO Global Database on Anaemia.Geneva: WHO. 2008.hlm.5-8.

4. Depkes RI. Survei kesehatan rumah tangga tahun 2005. Jakarta: Badan Penelitian Dan Pengembangan Kesehatan, Departemen Kesehatan Republik Indonesia; 2006.

5. WHO. Iron deficiency anemia, assessment, prevention and control, a guide for programe managers. Geneva: WHO; 2001.

6. Leginem. Faktor-faktor yang berhubungan dengan status anemi pada mahasiswi akademi bidan di Kota Banda Aceh 2002 (tesis). Jakarta: Pasca Sarjana Fakultas Kesehatan Masyarakat Uniersitas Indonesia; 2002.

7. Satyaningsih E. Anemia gizi pada remaja putri SMK Amaliyah Sekadau Kalimantan Barat Tahun 2007 (tesis). Jakarta: Pasca Sarjana Fakultas Kesehatan Masyarakat Uniersitas Indonesia; 2007.

8. Dinkes Kota Sawahlunto. Profil kesehatan Kota
Sawahlunto tahun 2013. Sawahlunto: Dinas Kesehatan:. 2013.

9. Nur Widianti. Hubungan antara body image dan perilaku makan dengan status gizi remaja putri di SMA Theresiana Semarang (skripsi). Semarang: Universitas Diponegoro. 2012

10. Mulyatni N. Faktor-faktor yang berhubungan dengan status gizi remaja putri pada SMUN dan MAN di Kota Padang Propinsi Sumatera Barat Tahun 2002 (tesis). Jakarta: Universitas Indonesia; 2002.

11. Laus MF, Mota DC, Moreira RC, Costa TM, Almeida S. Physical activity, nutritional status and body image concerns in adolescents. Journal Brazailian Psiquatr. 2009.58(3):150.

12. Kathlen L, Sylvia ES. Krause's food, nutrient and diet therapy. Edisi ke-12. Philadelphia: Saunders; 2008.hlm.257.

13. Kusumajaya NA, Wiardani NK, Juniarsana IW. Persepsi remaja terhadap body image kaitannya dengan pola konsumsi makan. Jurnal Skala Husada. 2008;5(2):114-25.

14. Kaur S, Deshmukh PR, Garg BS. Epidemiological correlates of nutritional anemia in adolescent girls of Rural Wardha. Indian Journal of Community Medicine. 2006;31(4):255-8.

15.Zimmerman MB, Klaus K. Nutritional anemia. Switzerland: Sight and Life Press; 2007. 218.

16. Yu Qin, Alida MB, Xiaoqun P, Baojun Y, Yue D, Jinkou $Z$, et al. Anemia in relation to body mass indexand waist circumference among chinese woman. Nutrition Journal. 2013;12(10):1-3.

17. Ramzi M, Haghpanah S, Malekmakan L, Cohan N, Baseri A, Alamdari A, et al. Anemia and iron deficiency in adolescent school girls in Kavar Urban Area, Southern Iran. Iran Red Crescent Med J. 2011. 13(2):128-33.

18. Eckhardt CL, Torheim LE, Monterrubio S Barquera MT Ruel. The overlap of overweight and anemia among women in three countries undergoing the nutrition trantition. European Journal of Clinical Nutrition. 2008.62: 238-46. 
19. Nead KG, Halterman JS, Kaczorowski JM, Auinger $P$, Weitzman $M$. Overweight children and adolescents: a risk group for iron deficiency. Pediatrics. 2004. 114(1):104-8.
20. Nadia FF, Naomi JS, Yara K, Romain AMD, Alidon $M B$, Inge DB. Weight status and iron deficiency among urban malian women of reproductive age. British Journal of Nutrition. 2010.105:574-9. 